\title{
THE INFLUENCE OF AQIDAH AKHLAK AND SOCIOLOGY LEARNING OUTCOMES ON THE FORMATION OF STUDENT CHARACTER
}

\author{
Eva Karlina Dwi Astuti'; Tarsono ${ }^{2}$; Yani Suryani ${ }^{3}$ \\ 1,2,3 Universitas Islam Negeri Sunan Gunung Djati, Bandung, Jawa Barat, Indonesia \\ 1evakarlina97@gmail.com; ${ }^{2}$ tarsono@uinsgd.ac.id; 3yan_dikha@yahoo.com
}

\begin{abstract}
This study aims to determine the effect of moral theology learning outcomes and sociology learning outcomes on the formation of student character. This research uses a quantitative approach, because the data presented is in the form of numbers. The method used is descriptive correlational. The research subjects were taken from 26th grade XI students. Data was collected using test, documentation and observation methods. Data were analyzed using IBM's SPSS version 26 application program. Hypothesis testing is done by statistical analysis techniques that are using multiple linear regression test. Based on the results of the study concluded that there is an influence of moral theology learning outcomes and sociology learning outcomes together can have an influence on student character. It is proven that the significance value of the regression in ANOVA test table is $0,000(<0.05)$, then Ho is rejected and $\mathrm{H} 1$ is accepted. The magnitude of influence is equal to $57.7 \%$.
\end{abstract}

Keywords: Learning outcomes; moral theology; Sociology; Character building.

\section{INTRODUCTION}

Character education plays a very important role in shaping character in students. Faith and devotion, responsibility, curiosity, competence, discipline and high tenacity can be possessed by students with character (Supriyadi, 2011). They will be better able to face life's challenges one day. Therefore, the values of character education are an aspect that must be instilled in educational institutions. One of the Islamic education institutions that can be used in the development of character education values is madrasas, which have integrated character values in religious subjects as a whole (Isnaini, 2013).

The results of observations at MA Darul Iman for class XI students obtained information that there are some students who rarely pray, are not responsible for doing assignments either individually or in groups, lack of 
curiosity, lack of knowledge, lack of discipline, lack of hard work and are less innovative, often late, lack of attendance, cheating, lack of cooperation, not obeying the applicable rules and many other actions of students with poor character.

Schools, especially religious education institutions, need to understand things that can have an influence on character building in students. Thinking and acting can be done in learning so that it reaches three domains, namely cognitive, affective, and psychomotor for life provisions (Lestiawan \& Johan, 2018). Active-cognitive learning research is a fundamental component of the education system (Karpov, 2017). So it is necessary to do research related to learning outcomes to determine the achievement of learning objectives. Learning outcomes are defined as changes in student behavior after they participate in learning activities (Mahmudi \& Shofro, 2019). This behavior change is a reflection of achievement after learning activities.

Subjects that can be used as tools in character building are Aqidah Akhlak and Sociology subjects. This is evidenced by the findings which state that character building through the delivery of Aqidah Akhlak learning produces very satisfying results (Putra, 2017). In addition, other findings also state that the internalization of disciplinary values can be inserted into sociology subjects, then applied in school discipline (Puspasari et al., 2013). These findings can be used as a basis for this research, resulting in new findings.

Based on the background of the problem, this research wants to know whether or not the influence of Aqidah Akhlak learning outcomes and Sociology learning outcomes on the character building of class XI students at MA Darul Iman, West Bandung Regency. 


\section{THEORETICAL BASIS}

\section{Character Education}

Etymologically, character is defined as character/habit. According to psychologists, character is a belief system and habits that govern a person's actions. Character is also referred to as morals based on an Islamic point of view, which means a trait that arises from a person's heart to act spontaneously and without consideration (Isnaini, 2013). The word character is also often interpreted as character. Embedding character is not easy, it needs a long process, namely through education (Al-Anwari, 2014). Education is an effort to change student behavior so that they become mature and independent individuals in their surroundings (Sagala, 2014:3). As for education in schools, it is expected that graduates have reached a level of development in basic skills, the ability to think critically, plan studies and the future (Reiska et al., 2018).

Human resources with good character are needed in national development (Suastra et al., 2017). Early childhood education and high quality parenting experience are very important for the growth and development of children (Megalonidou, 2020). Therefore, it is necessary to have education that directs the development of children's character. Character education is moral education as a whole, including cognitive, affective, and psychomotor aspects (Isnaini, 2013). So that students not only know, but also have the desire and are able to carry it out (Al-Anwari, 2014). Character education can develop well if a religious spirit is instilled in children, therefore the material of aqidah in Islamic Education is transformed into one of the supports in building student character (Ainiyah, 2013). Character planting can be done during teaching and learning activities in the presence of stimulus and responses as in behavioristic learning theory.

Behavioristic theory states that learning is a behavior change in a person that results from learning experience, the originators of this theory are Gagne and Berliner. These behavioral changes can be measured, observed, and 
assessed in real terms (Thobroni, 2015: 56-57). In other words, this shows that there is a need for education and teaching that leads to character building. The formation in behavioral learning theory is used to refer to the teaching of new behaviors by strengthening students to approach behaviors that match expectations (Slavin, Robert E, 2011: 190). This behavior will appear as a result of experience or learning outcomes so that this behavior will be embedded into a character for students.

\section{Learning outcomes}

Learning outcomes are the achievement of goals for students after experiencing the learning process (Purwanto, 2016). Learning outcomes are changes in behavior and learning achievement of students according to learning objectives after experiencing the learning process (Mahmudi \& Shofro, 2019). A person is stated to have learned when he has experienced a change in behavior. Of course, with a change in behavior that is not good to good, then good to better.

According to Boom's taxonomy, learning outcomes are classified into three aspects, namely cognitive (memory), affective (feeling) and psychomotor (ability and skills) (Arikunto, 2016). These three aspects need to be developed thoroughly, not just promoting one of them. Thus, learning objectives can be achieved effectively as expected.

The term aqidah is defined as something that must be declared true in the human heart and soul so that he feels at ease with him which grows into a belief without any doubts (Putra, 2017). Then, morals are defined as actions that are firmly embedded in the human soul into personalities so that they do it spontaneously without thinking (Suryawati, 2016). When aqidah has been embedded in the human soul, an action will emerge as a form of its implementation from learning outcomes.

The existence of learning aqidah akhlak is expected to produce a behavior change in students after they experience the learning process. 
Aqidah Akhlak teaches how to behave properly in accordance with the Shari'a such as: ethics, manners, norms, how to get along, respect people and so on (Yanti, 2017). Aqidah akhlak education is closely related to character education which includes hablum minallah and hablum minannas. The goal is to create kamil people (Suryawati, 2016). Thus, learning aqidah morals can form humans with noble characters as a form of learning outcomes.

Apart from aqidah akhlak, sociology learning also contributes to character building, this can be seen in formal education institutions at the high school level (SMA) (Putri, 2011). The internalization of character can be carried out by teachers in sociology subjects by prioritizing values that will be applied such as discipline and sanctions if there is a violation (Puspasari et al., 2013). Thus, these character values will be firmly embedded in students so that they form a personality.

Character values are not like ordinary subject teaching materials, but need to be internalized in the learning process (Fatmah et al., 2014). So there needs to be a long enough process to instill good habits according to learning objectives. One of them is through the sociology learning process, especially in cultivating the habit of living in a social environment in accordance with the rules.

According to Albert Bandura, the behavior displayed by humans can be predicted and modified with learning principles that still pay attention to the way of thinking and social relationships (Tarsono, 2010). This is certainly in line with the sociology subject matter which teaches students to behave well in their social life. This behavior can be measured from the acquisition of student learning outcomes.

\section{METHOD}

This study uses a quantitative approach, because the data listed is in the form of numbers. The method used is descriptive correlational to determine the relationship between variables. The research subjects were class XI 
students at MA Darul Iman West Bandung Regency who were taken as a whole because there was only one class of 26 students. Sources of data are taken from the final grades of students' Aqidah Akhlak and Sociology and from the observations of subject teachers. There are three variables in this study, namely variable $\mathrm{X}_{1}$ (the influence of the learning outcomes of aqidah Akhlak) variable $\mathrm{X}_{2}$ (the effect of sociological learning outcomes) and variable $\mathrm{Y}$ (the formation of student character). The variables $\mathrm{X}_{1}$ and $\mathrm{X}_{2}$ are independent variables, while variable $\mathrm{Y}$ is the dependent variable.

Data were collected using the test method to determine sociology learning outcomes, documentation to collect data on learning outcomes of Aqidah Akhlak from teachers, and observations to collect data related to student character at school. The data collection tool uses a check list using a Likert scale to measure student character. There are 4 alternative answers, namely very good, good, sufficient, and less. The aspects that are assessed in character building are prayer worship, responsibility, curiosity, deepening knowledge, discipline, hard work and creativity.

Data analysis was performed with the help of IBM's version 26 SPSS application program to perform conditional tests, namely: normality test, multicolinearity, heteroscedasticity and autocorrelation. Many assessment and evaluation studies use statistical hypothesis testing, such as the independent sample $t$ test or analysis of variance, to test the equation for two or more variables (Nordstokke et al., 2011). As for testing the hypothesis in this study using statistical analysis techniques, namely multiple linear regression test.

\section{RESULTS AND DISCUSSION}

\section{RESULTS}

\section{Descriptive statistics}

Descriptive statistics describe or describe data seen from the mean / average, standard deviation, and the number of data / samples (Suryani \& 
Habibie, 2017). The following table describes the statistics in this study, namely:

Tabel 1. Descriptive statistics

\begin{tabular}{lrrr}
\hline \multicolumn{4}{c}{ Descriptive Statistics } \\
& Mean & Std. Deviation & N \\
\hline Character_Student & 5.4769 & .56449 & 26 \\
Result_Study_Aqidah_Akhlak & 78.0769 & 3.35765 & 26 \\
Result_Study_Sosiology & 77.8462 & 6.98966 & 26 \\
\hline
\end{tabular}

In table 1, it can be seen that the average (mean) score for student character is 5.4769 , the learning outcomes of aqidah morals are 78.07 , and the sociology learning outcomes are 77.84. The standard deviation for student character is 0.564 , the learning outcomes of aqidah akhlak are 3.357, and the sociology learning outcomes are 6.989. The amount of data for the three variables $(\mathrm{N})$ is 26 .

\section{Classic Assumption Test}

Multiple linear regression analysis simultaneously with the classic assumption test (Normality, Multicollinearity, Heteroscedasticity, and Autocorrelation) simultaneously which will be detailed as follows:

\section{a. Results of Data Normality Test Analysis}

1) Testing the normality of data on multiple linear regression using the Probability Plot

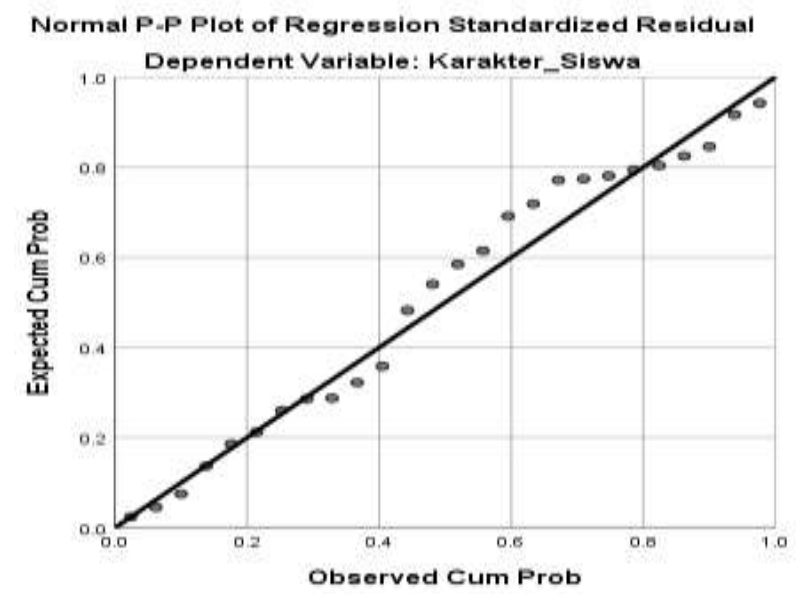

Picture 1. Probability Plot 
Picture 1 illustrates that the data is scattered along the diagonal line (near the diagonal line). So the conclusion is that the regression model is normally distributed.

2) Testing the normality of data on multiple linear regression using a histogram, the following results:

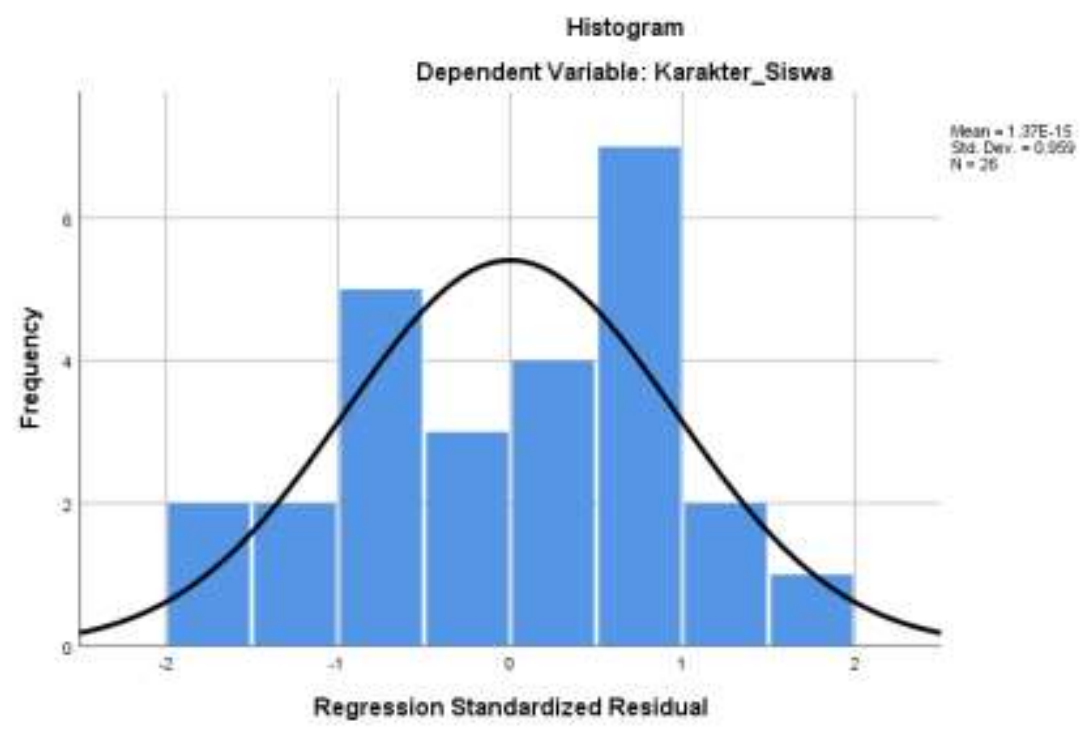

Picture 2. Histogram

Picture 2 shows that the curve forms a curve of the norm curve (similar to a bell), then the residual is declared normal so that the assumption of normality of the data is fulfilled. Thus, the conclusion is that the regression model is normally distributed.

3) Testing data normality on multiple linear regression using the OneSample Kolmogorov-Smirnov Test

If you are in doubt about the Probability Plot and Histogram, because it uses graphs, then you can use an alternative test, namely by using the One-Sample Kolmogorov-Smirnov Test. This is because each person's interpretation can be different, there are many elements of subjectivity. The following SPSS output concerns: 
Table 2. One-Sample Kolmogorov-Smirnov Test

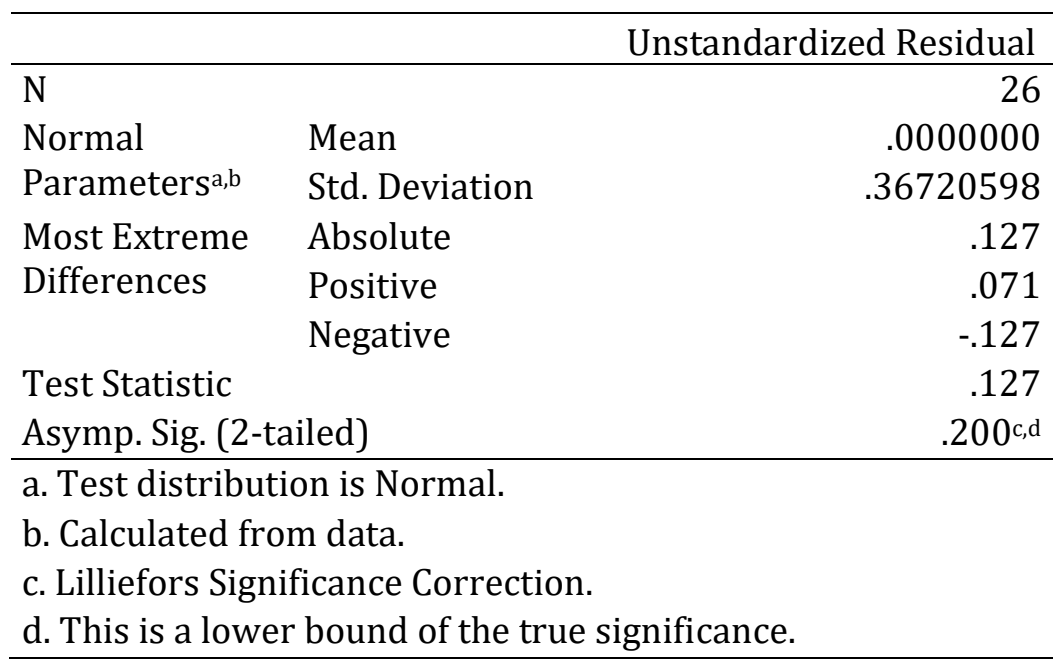

Basic decision making:

$\circ$ If the value is sig. $>0.05$, the residual data is normally distributed

$\circ$ If the value is sig. $<0.05$, the residual data is not normally distributed

Based on table 2 it shows that the significance value is 0.200 (> 0.05), so the conclusion is that the residual data is normally distributed or the regression model is normally distributed.

\section{b. Results of Multicolinearity Test Analysis}

Basis for decision making based on Tolerance value:

$\circ$ If the Tolerance value $>0.10$ means that there is no multicolinearity in the Regression model

$\circ$ If the Tolerance value $<0.10$ means that there is multicolinearity in the Regression model

Basis for decision making based on VIF value:

○ If the VIF value $<10$ means that there is no multicolinearity in the Regression model

$\circ$ If the VIF value $>10$ means that there is multicolinearity in the Regression model 
Table 3. Multicollinearity Test Results

\begin{tabular}{|c|c|c|c|c|c|c|c|}
\hline \multicolumn{8}{|c|}{ Coefficients $^{\mathbf{a}}$} \\
\hline \multirow[b]{2}{*}{ Model } & \multicolumn{2}{|c|}{$\begin{array}{l}\text { Unstandardized } \\
\text { Coefficients }\end{array}$} & \multirow{2}{*}{$\begin{array}{c}\text { Standardized } \\
\text { Coefficients } \\
\text { Beta }\end{array}$} & \multirow[b]{2}{*}{$\mathrm{T}$} & \multirow[b]{2}{*}{ Sig. } & \multicolumn{2}{|c|}{$\begin{array}{l}\text { Collinearity } \\
\text { Statistics }\end{array}$} \\
\hline & B & $\begin{array}{l}\text { Std. } \\
\text { Error }\end{array}$ & & & & Tolerance & VIF \\
\hline 1 (Constant) & -.793 & 1.843 & & -.431 & .671 & & \\
\hline $\begin{array}{l}\text { Result_Study_Aq } \\
\text { idah_Akhlak }\end{array}$ & .030 & .031 & .176 & .960 & .347 & .546 & 1.831 \\
\hline $\begin{array}{l}\text { Result_Study_So } \\
\text { siology }\end{array}$ & .051 & .015 & .630 & 3.430 & .002 & .546 & 1.831 \\
\hline
\end{tabular}

In table 3, note the Collinearity Statistics, the Tolerance value for Aqidah Akhlak Learning Outcomes (X1) and Sociology Learning Outcomes (X2) is $0.546(>0.10)$ and the VIF value for Aqidah Akhlak Learning Outcomes (X1) and Sociology Learning Outcomes (X2) is $1,831(<10)$, so the conclusion is that there is no multicollinearity symptom in the regression model.

\section{c. Result of Heteroscedasticity Test Analysis}

1) Scatterplots chart

Basic decision making with Scatterplots chart

O If there is No. clear pattern, namely the distribution points are above and below the number 0 on the $\mathrm{Y}$ axis, then there is No. symptom of heteroscedasticity.

O If there is a certain clear pattern, namely the dots form a certain pattern, then there is a symptom of heteroscedasticity

Here is the SPSS output: 
Astuti, E.K.D., Tarsono, Suryani, Y. (2020). THE INFLUENCE OF AQIDAH AKHLAK AND SOCIOLOGY LEARNING OUTCOMES ON THE FORMATION OF STUDENT CHARACTER. Jurnal Tatsqif, 18 (1), 77-96. https://doi.org/10.20414/itq.v17i2.2380

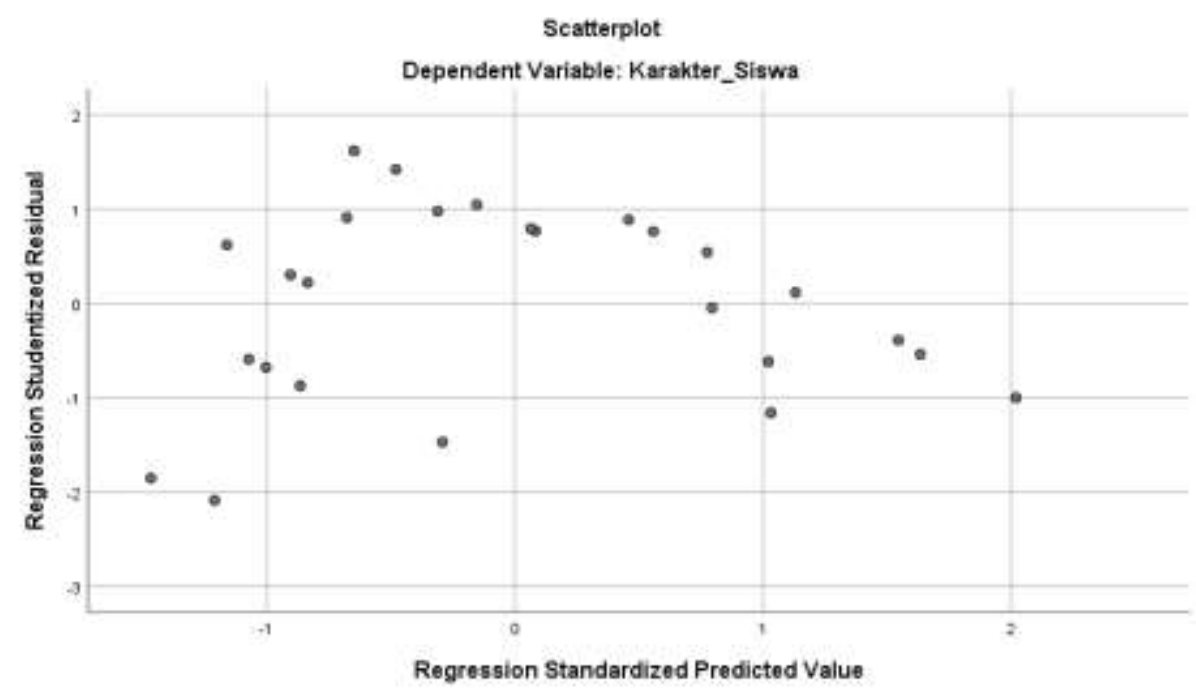

Picture 3. Scatterplots

Based on picture 3, it can be seen that the data points do not form a certain pattern and spread above and below the number 0 on the $\mathrm{Y}$ axis (vertical axis), so it can be concluded that there are no symptoms of heteroscedasticity.

2) Glejser test

Next we will perform the Glejser test for the regression equation of Aqidah Akhlak Learning Outcomes (X1) and Sociology Learning Outcomes (X2) on the Absolute Residual or Abs_Res variable. The results of the Heteroscedasticity test output, through the following Coefficients table:

Table 4. Glejser Test Results

\begin{tabular}{|c|c|c|c|c|c|c|c|}
\hline \multirow[b]{3}{*}{ Model } & \multicolumn{5}{|c|}{ Coefficients $^{a}$} & & \\
\hline & \multicolumn{2}{|c|}{$\begin{array}{l}\text { Unstandardized } \\
\text { Coefficients }\end{array}$} & \multirow{2}{*}{$\begin{array}{c}\begin{array}{c}\text { Standardized } \\
\text { Coefficients }\end{array} \\
\text { Beta }\end{array}$} & \multirow[b]{2}{*}{$\mathrm{T}$} & \multirow[b]{2}{*}{ Sig. } & \multicolumn{2}{|c|}{$\begin{array}{l}\text { Collinearity } \\
\text { Statistics }\end{array}$} \\
\hline & $\mathrm{B}$ & Std. Error & & & & Tolerance & VIF \\
\hline 1 (Constant) & 1.509 & .860 & & 1.755 & .093 & & \\
\hline $\begin{array}{l}\text { Result_Study_Aqi } \\
\text { dah_Akhlak }\end{array}$ & -.008 & .014 & -.139 & -.535 & .598 & .546 & 1.831 \\
\hline $\begin{array}{l}\text { Result_Study_Sos } \\
\text { iology }\end{array}$ & -.008 & .007 & -.287 & -1.108 & .279 & .546 & 1.831 \\
\hline
\end{tabular}


Through table 4, the Abs_Res variable as the dependent variable (the dependent variable), it can be seen that the Sig value on the Aqidah Akhlak Learning Outcomes is 0.598 and the Sig value on the Sociology Learning Outcomes is 0.279 . The sig value of the two variables is $>0.05$, so the conclusion is that there are no symptoms of heteroscedasticity.

\section{d. Autocorrelation Test Results}

According to Ghazali, "There is no autocorrelation symptom if the $d$ (durbin-warston) value is between the dU (Upper durbin) and the (4-du) value (Ghozali, 2011).

$\mathrm{dU}<\mathrm{d}<4-\mathrm{dU}$

To find out the value of $d$ (durbin Watson) have a look at the following SPSS output:

Table 5. Autocorrelation Test Results

\begin{tabular}{lcccrr}
\hline \multicolumn{5}{c}{ Model Summary $^{\mathbf{b}}$} \\
Adjusted R \\
Model & $\mathrm{R}$ & R Square & Square & $\begin{array}{c}\text { Std. Error of } \\
\text { the Estimate }\end{array}$ & Durbin-Watson \\
\hline 1 & $.394^{\mathrm{a}}$ & .156 & .082 & .17869 & 1.377 \\
\hline $\begin{array}{l}\text { a. Predictors: (Constant), Result_Study_Sosiology, Result_Study_Aqidah_Akhlak } \\
\text { b. Dependent Variable: Abs_Res }\end{array}$
\end{tabular}

In table 5 above, it can be seen that the value $d=1.377$. The value of $\mathrm{du}$ is obtained from the Durbin-Watson Table with $\mathrm{k}=2$ (number of independent variables) and $n=26$ (amount of data) with a significance of $5 \%$. As follows:

Table 6. Durbin-Watson

\begin{tabular}{|r|r|r|r|r|r|r|r|r|r|r|}
\hline & \multicolumn{2}{|c|}{$\mathrm{k}=1$} & \multicolumn{2}{|c|}{$\mathrm{k}=2$} & \multicolumn{2}{c|}{$\mathrm{k}=3$} & \multicolumn{2}{|c|}{$\mathrm{k}=4$} & \multicolumn{2}{|c|}{$\mathrm{k}=5$} \\
\cline { 2 - 10 } $\mathrm{n}$ & $\mathrm{dL}$ & $\mathrm{dU}$ & $\mathrm{dL}$ & $\mathrm{dU}$ & $\mathrm{dL}$ & $\mathrm{dU}$ & $\mathrm{dL}$ & $\mathrm{dU}$ & $\mathrm{dL}$ & $\mathrm{dU}$ \\
\hline 6 & 0.6102 & 1.4002 & & & & & & & & \\
7 & 0.6996 & 1.3564 & 0.4672 & 1.8964 & & & & & & \\
8 & 0.7629 & 1.3324 & 0.5591 & 1.7771 & 0.3674 & 2.2866 & & & & \\
9 & 0.8243 & 1.3199 & 0.6291 & 1.6993 & 0.4548 & 2.1282 & 0.2957 & 2.5881 & & \\
10 & 0.8791 & 1.3197 & 0.6972 & 1.6413 & 0.5253 & 2.0163 & 0.3760 & 2.4137 & 0.2427 & 2.8217 \\
11 & 0.9273 & 1.3241 & 0.7580 & 1.6044 & 0.5948 & 1.9280 & 0.4441 & 2.2833 & 0.3155 & 2.6446
\end{tabular}


Astuti, E.K.D., Tarsono, Suryani, Y. (2020). THE INFLUENCE OF AQIDAH AKHLAK AND SOCIOLOGY LEARNING OUTCOMES ON THE FORMATION OF STUDENT CHARACTER. Jurnal Tatsqif, 18 (1), 77-96. https://doi.org/10.20414/jtq.v17i2.2380

\begin{tabular}{|r|r|r|r|r|r|r|r|r|r|r|}
\hline & \multicolumn{2}{|c|}{$\mathrm{k}=1$} & \multicolumn{2}{|c|}{$\mathrm{k}=2$} & \multicolumn{2}{|c|}{$\mathrm{k}=3$} & \multicolumn{2}{|c|}{$\mathrm{k}=4$} & \multicolumn{2}{|c|}{$\mathrm{k}=5$} \\
\cline { 2 - 10 } $\mathrm{n}$ & $\mathrm{dL}$ & $\mathrm{dU}$ & $\mathrm{dL}$ & $\mathrm{dU}$ & $\mathrm{dL}$ & $\mathrm{dU}$ & $\mathrm{dL}$ & $\mathrm{dU}$ & $\mathrm{dL}$ & $\mathrm{dU}$ \\
\hline 12 & 0.9708 & 1.3314 & 0.8122 & 1.5794 & 0.6577 & 1.8640 & 0.5120 & 2.1766 & 0.3796 & 2.5061 \\
13 & 1.0097 & 1.3404 & 0.8612 & 1.5621 & 0.7147 & 1.8159 & 0.5745 & 2.0943 & 0.4445 & 2.3897 \\
14 & 1.0450 & 1.3503 & 0.9054 & 1.5507 & 0.7667 & 1.7788 & 0.6321 & 2.0296 & 0.5052 & 2.2959 \\
15 & 1.0770 & 1.3605 & 0.9455 & 1.5432 & 0.8140 & 1.7501 & 0.6852 & 1.9774 & 0.5620 & 2.2198 \\
16 & 1.1062 & 1.3709 & 0.9820 & 1.5386 & 0.8572 & 1.7277 & 0.7340 & 1.9351 & 0.6150 & 2.1567 \\
17 & 1.1330 & 1.3812 & 1.0154 & 1.5361 & 0.8968 & 1.7101 & 0.7790 & 1.9005 & 0.6641 & 2.1041 \\
18 & 1.1576 & 1.3913 & 1.0461 & 1.5353 & 0.9331 & 1.6961 & 0.8204 & 1.8719 & 0.7098 & 2.0600 \\
19 & 1.1804 & 1.4012 & 1.0743 & 1.5355 & 0.9666 & 1.6851 & 0.8588 & 1.8482 & 0.7523 & 2.0226 \\
20 & 1.2015 & 1.4107 & 1.1004 & 1.5367 & 0.9976 & 1.6763 & 0.8943 & 1.8283 & 0.7918 & 1.9908 \\
21 & 1.2212 & 1.4200 & 1.1246 & 1.5385 & 1.0262 & 1.6694 & 0.9272 & 1.8116 & 0.8286 & 1.9635 \\
22 & 1.2395 & 1.4289 & 1.1471 & 1.5408 & 1.0529 & 1.6640 & 0.9578 & 1.7974 & 0.8629 & 1.9400 \\
23 & 1.2567 & 1.4375 & 1.1682 & 1.5435 & 1.0778 & 1.6597 & 0.9864 & 1.7855 & 0.8949 & 1.9196 \\
24 & 1.2728 & 1.4458 & 1.1878 & 1.5464 & 1.1010 & 1.6565 & 1.0131 & 1.7753 & 0.9249 & 1.9018 \\
25 & 1.2879 & 1.4537 & 1.2063 & 1.5495 & 1.1228 & 1.6540 & 1.0381 & 1.7666 & 0.9530 & 1.8863 \\
26 & 1.3022 & 1.4614 & 1.2236 & 1.5528 & 1.1432 & 1.6523 & 1.0616 & 1.7591 & 0.9794 & 1.8727 \\
27 & 1.3157 & 1.4688 & 1.2399 & 1.5562 & 1.1624 & 1.6510 & 1.0836 & 1.7527 & 1.0042 & 1.8608 \\
\hline
\end{tabular}

Based on Durbin-Watson's table 6, we will prove whether: $\mathrm{dU}<\mathrm{d}<4$ dU. Obtained the value of $d U=1.5528$, the value of $d=1.377$, and the value of $4-\mathrm{dU}=4-1.5528=2.4472$. Thus $\mathrm{dU}(1.5528)>\mathrm{d}(1.377)<4-\mathrm{dU}$ (2.4472), so the statement $d U<d<4-d U$ is false. Because the $d$ (durbinwarton) value does not lie between the dU (Upper durbin) value and the 4du value, it means that there is a symptom of autocorrelation.

\section{Hypothesis test}

\section{a. Partial t test}

Starting from the Partial t test on Multiple Linear Regression, Partial $t$ test is a test of the influence of variable $\mathrm{X}$ independently of variable $\mathrm{Y}$. Basis for Decision Making

O If the Sig value $>0.05$, the independent variable $(\mathrm{X})$ partially (individually) has no effect on the dependent variable (Y)

$\circ$ If the Sig value $<0.05$ then the independent variable $(X)$ partially (individually) affects the dependent variable (Y)

The following is the output of the SPSS partial t test 
Table 7. Partial t test results

\begin{tabular}{|c|c|c|c|c|c|c|c|c|}
\hline \multicolumn{9}{|c|}{ Coefficients $^{\mathrm{a}}$} \\
\hline & & \multicolumn{2}{|c|}{$\begin{array}{l}\text { Unstandardized } \\
\text { Coefficients }\end{array}$} & \multirow{2}{*}{$\begin{array}{c}\text { Standardized } \\
\text { Coefficients } \\
\text { Beta }\end{array}$} & \multirow[b]{2}{*}{$\mathrm{T}$} & \multirow[b]{2}{*}{ Sig. } & \multicolumn{2}{|c|}{$\begin{array}{c}\text { Collinearity } \\
\text { Statistics }\end{array}$} \\
\hline \multicolumn{2}{|c|}{ Model } & B & Std. Error & & & & Tolerance & VIF \\
\hline \multirow[t]{3}{*}{1} & (Constant) & -.793 & 1.843 & & -.431 & .671 & & \\
\hline & $\begin{array}{l}\text { Result_Study_Aqidah } \\
\text { Akhlak }\end{array}$ & .030 & .031 & .176 & .960 & .347 & .546 & 1.831 \\
\hline & $\begin{array}{l}\text { Result_Study_- } \\
\text { Sosiology }\end{array}$ & .051 & .015 & .630 & 3.430 & .002 & .546 & 1.831 \\
\hline
\end{tabular}

Basic decision making:

$\circ$ If the Sig value is greater ( $>0.05)$, then Ho is accepted

○ If the Sig value is smaller $(<0.05)$, then Ho is rejected

Hypothesis 1:

Ho = There is no effect of learning outcomes of aqidah morals on the character building of students

$\mathrm{H} 1$ = There is an effect of learning outcomes of aqidah morals on the character building of students

The Sig value for the Aqidah Akhlak Learning Outcomes variable is 0.347 ( $>0.05$ ), so Ho is accepted, so the conclusion is: "There is no effect of learning outcomes of aqidah akhlak on the formation of student character".

Hypothesis 2:

Ho = There is no effect of sociology learning outcomes on the character building of students

$\mathrm{H} 1$ = There is an effect of sociology learning outcomes on the character building of students

The Sig value for the Sociology Learning Outcomes variable was 0.002 $(<0.05)$, so Ho was rejected so the conclusion was: "There is an effect of sociology learning outcomes on the character building of students".

The regression equation:

$\mathrm{Y}=\mathrm{a}+\mathrm{b}_{1} \mathrm{X}_{1}+\mathrm{b}_{2} \mathrm{X}_{2} \quad \mathrm{Y}=-0,793+0,030 \mathrm{X}_{1}+0,051 \mathrm{X}_{2}$ 
Based on the regression equation, it can be seen that the constant a is 0.793; meaning that if the Aqidah Akhlak Learning Outcomes (X1) are equal to zero (no change), then the Student Character (Y) is also -0.793 . The regression coefficient for the Aqidah Akhlak Learning Outcomes variable $(\mathrm{X} 1)$ is $\mathrm{b} 1=0.030$ (positive / unidirectional) meaning that there is a positive relationship between Aqidah Akhlak Learning Outcomes (X1) and Student Character (Y), so that the Aqidah Akhlak Learning Outcomes (X1) will increase. the higher the student character (Y). If the Aqidah Akhlak Learning Outcomes increase by 0.030 , the Student Character will also increase by 0.030 .

The regression coefficient for the Sociology Learning Outcomes variable (X2), namely b2 $=0.051$ (positive / unidirectional) means that there is a positive relationship between Sociology Learning Outcomes (X2) and Student Character (Y), so that the higher the Sociology Learning Outcomes (X2), the higher it is. Student Character (Y). If the Sociology Learning Outcomes increase by 0.051 , the Student Character will also increase by 0.051 .

\section{b. Simultaneous F Test}

Furthermore, simultaneous F test on Multiple Linear Regression is to test the effect of the two variables X simultaneously on variable Y. Here is the sound of the hypothesis:

$\mathrm{H}_{0}=$ There is no effect of learning outcomes of aqidah morals and sociology learning outcomes on student character

$\mathrm{H}_{1}=$ There is an effect of learning outcomes of aqidah morals and sociology learning outcomes on student character

Basic decision making:

○ If the Sig $>0.05$ then Ho is accepted

$\circ$ If the Sig $<0.05$ then Ho is rejected

The output from SPSS we see the following F test results: 
Table 8. Simultaneous F Test Results

\begin{tabular}{|c|c|c|c|c|c|c|}
\hline \multicolumn{7}{|c|}{ ANOVAa $^{a}$} \\
\hline \multicolumn{2}{|c|}{ Model } & Sum of Squares & Df & Mean Square & $\mathrm{F}$ & Sig. \\
\hline 1 & Regression & 4.595 & 2 & 2.298 & 15.676 & $.000^{\mathrm{b}}$ \\
\hline & Residual & 3.371 & 23 & .147 & & \\
\hline & Total & 7.966 & 25 & & & \\
\hline
\end{tabular}

a. Dependent Variable: Character_Student

b. Predictors: (Constant), Result_Study_Sosiology, Result_Study_Aqidah_Akhlak

Seen in table 8 anova Sig value for regression of $0.000(<0.05)$, then Ho is rejected and $\mathrm{H} 1$ is accepted so that the conclusion: "There is an effect of learning outcomes of aqidah morals and sociology learning outcomes on the formation of student character" or it can be said that "learning outcomes Aqidah morals and sociology learning outcomes can both have an influence on the character building of students.

Furthermore, to see how much influence the independent variables have on the dependent variable either partially or simultaneously, it can be seen that the following SPSS outputs are:

Table 9. Model Summary

\begin{tabular}{|c|c|c|c|c|c|}
\hline \multicolumn{6}{|c|}{ Model Summaryb } \\
\hline Model & $\mathrm{R}$ & R Square & $\begin{array}{l}\text { Adjusted R } \\
\text { Square }\end{array}$ & $\begin{array}{l}\text { Std. Error of } \\
\text { the Estimate }\end{array}$ & Durbin-Watson \\
\hline 1 & $.759^{a}$ & .577 & .540 & .38284 & 1.768 \\
\hline
\end{tabular}

In table 9, it is known that the Coefficient of Determination (R Square or R Squared) in Multiple Linear Regression has the meaning "How much (\%) the contribution / contribution / influence is given by the variables X1 (Aqidah Akhlak Learning Outcomes) and X2 (Sociology Learning Outcomes) simultaneously ( together) to the variable Y (Student Character) "

The value of R Square is 0.577 or $57.7 \%$, so it can be said that the learning outcomes of aqidah akhlak and sociology learning outcomes 
together have an influence of $57.7 \%$ on character formation, while the remaining $47.3 \%$ are influenced by other factors.

\section{DISCUSSION}

The results of data analysis from this study using multiple linear regression test at a significance level of $\alpha 0.05$ obtained a significance value of 0.000 smaller than 0.05 , so there is an effect of learning aqidah akhlak and sociology learning outcomes on character building of MA Darul Iman students. West Bandung Regency.

Students are subjects in learning that require the cultivation of character values so that they become individuals who are ready to face various challenges someday. Character can be the main asset for students to behave in their environment. The good and bad character of a person can be described through their behavior in everyday life. Character can also be influenced by various aspects including through education and learning. Especially in the subjects of aqidah morals and sociology at Madrasah Aliyah (MA).

Madrasah is a formal educational institution in which it provides various teachings to mature students. One of them is through the subject of aqidah morals, students are taught how to behave properly in accordance with the law such as: ethics, manners, norms, how to get along, respect people and so on (Yanti, 2017). That way students can find out about good and bad based on Islamic law, so that they are aware to always behave well. This proves that learning aqidah morals in Madrasahs contributes to the formation of student character in accordance with the Shari'a. These characters can be firmly embedded in students by teaching, role models and habituation.

In addition, character planting can also be done through sociology learning in schools / madrasas that prioritizes character values such as discipline and penalties for violations (Puspasari et al., 2013). Such as the enactment of rules that are applied in schools such as how to wear, enter 
class, courtesy to teachers and fellow students, and so on. This is done in order to form students with character according to the rules of both religion and state.

If education, teaching and habituation are continuously carried out, these characters will be embedded in the souls of students and applied in everyday life in the form of behavior that matches the expectations of educational goals. Likewise, the behavior patterns in behaving and speaking can be well controlled.

\section{CONCLUSION}

Based on the results of data analysis, the authors conclude that there is an effect of aqidah akhlak learning outcomes and sociology learning outcomes together can have an influence on the character formation of class XI students of MA Darul Iman, West Bandung Regency. It is proven that the significance value for regression in the anova test table is $0.000(<0.05)$, so Ho is rejected and $\mathrm{H} 1$ is accepted. The amount of influence is equal to $57.7 \%$.

\section{REFERENCES}

Ainiyah, N. (2013). Pembentukan Karakter Melalui Pendidikan Agama Islam. Jurnal Al-Ulum, 13, 25-38.

Al-Anwari, A. M. (2014). Strategi Pembentukan Karakter Peduli Lingkungan Di Sekolah Adiwiyata Mandiri. TA'DIB, Vol. XIX(No. 02), 227-252.

Arikunto, S. (2016). Dasar-Dasar Evaluasi Pendidikan (Edisi 2). Bumi Aksara.

Fatmah, Pargito, \& Trisnaningsih. (2014). Nilai Karakter Dan Hasil Pembelajaran Sosiologi. Jurnal Studi Sosial, Vol. 2(No.2), 1-12.

Ghozali, I. (2011). Aplikasi Analisis Multivariate Dengan Program IBM SPSS 19. Badan Penerbit-Undip.

Isnaini, M. (2013). Internalisasi Nilai-Nilai Pendidikan Karakter Di Madrasah. Jurnal Al-Ta'lim, Jilid 1(No. 6), 445-450. 
Karpov, A. O. (2017). Education for Knowledge Society: Learning and Scientific Innovation Environment. Journal of Social Studies Education Research, 8(3), 201-214.

Lestiawan, F., \& Johan, A. B. (2018). Penerapan Metode Pembelajaran Example Nonexample untuk Meningkatkan Keaktifan dan Hasil Belajar Dasar-dasar Pemesinan. Jurnal Taman Vokasi, Vol. 6(No. 1), Hal. 98-106. Mahmudi, I., \& Shofro, M. L. (2019). Peningkatan Hasil Belajar Tarikh Islam Melalui Strategi Pembelajaran Everyone Is A Teacher Here Pada Siswi Kelas 2 KMI Pondok Modern Darussalam Gontor Putri. JURNAL TATSQIF: Jurnal Pemikiran Dan Penelitian Pendidikan, Vol. 17(No. 2), 171-186.

Megalonidou, C. (2020). The quality of early childhood education and care services in Greece. International Journal of Child Care and Education Policy, 14(9), 1-12. https://doi.org/10.1186/s40723-020-00074-2

Nordstokke, D. W., Zumbo, B. D., Cairns, S. L., \& Saklofske, D. H. (2011). The operating characteristics of the nonparametric Levene test for equal variances with assessment and evaluation data. Practical Assessment, Research, and Evaluation, 16(5), 1-8. https://doi.org/10.7275/5T99ZV93

Purwanto. (2016). Evaluasi Hasil Belajar. Pustaka Pelajar.

Puspasari, E., Zakso, A., \& Budjang, G. (2013). INTERNALISASI KARAKTER DISIPLIN SISWA PADA MATA PELAJARAN SOSIOLOGI (Studi di SMA Negeri 5 Pontianak). Jurnal Pendidikan Dan Pembelajaran Khatulistiwa, Vol. 2 (No. 2). http://jurnal.untan.ac.id/index.php/jpdpb/article/ view/1087

Putra, P. (2017). IMPLEMENTASI PENDIDIKAN KARAKTER DALAM PEMBELAJARAN AQIDAH AKHLAK (Studi Multi Kasus di MIN Sekuduk dan MIN Pemangkat Kabupaten Sambas). AL-BIDAYAH: Jurnal Pendidikan Dasar Islam, Vol. 9(No. 02), 147-156. 
Putri, N. A. (2011). Penanaman Nilai-Nilai Pendidikan Karakter Melalui Mata Pelajaran Sosiologi. Jurnal Komunitas, Vol. 3(No. 2), 205-215.

Reiska, P., Soika, K., \& Cañas, A. J. (2018). Using concept mapping to measure changes in interdisciplinary learning during high school. Knowledge Management \& E-Learning: An International Journal, 10(1), 1-24. https://doi.org/10.34105/j.kmel.2018.10.001

Sagala, S. (2014). Konsep dan Makna Pembelajaran: Vol. Cet. 12. Alfabeta CV. Slavin, Robert E. (2011). Psikologi Pendidikan Teori dan Praktik. PT Indeks.

Suastra, I. W., Jatmiko, B., Ristiati, N. P., \& Yasmini, L. P. B. (2017). Developing Characters Based on Local Wisdom of Bali in Teaching Physics in Senior High School. Jurnal Pendidikan IPA Indonesia, 6(2), 306-312. https://doi.org/10.15294/jpii.v6i2.10681

Supriyadi, E. (2011). Pendidikan dan Penilaian Karakter Di Sekolah Menengah Kejuruan. Cakrawala Pendidikan, Edisi Khusus Dies Natalis $U N Y, 110-123$.

Suryani, Y., \& Habibie, A. (2017). Analisis Pengaruh Rasio-rasio Risk Based Bank Rating terhadap Pertumbuhan Laba Pada Perusahaan Perbankan yang Terdaftar Di Bei. KITABAH, Volume 1(No. 1), 46-68.

Suryawati, D. P. (2016). Implementasi Pembelajaran Akidah Akhlak Terhadap Pembentukan Karakter Siswa di MTs Negeri Semanu Gunungkidul. Jurnal Pendidikan Madrasah, Vol. 1(No. 2), 309-322.

Tarsono. (2010). Implikasi Teori Belajar Sosial (Social Learning Theory) dari Albert Bandura dalam Bimbingan dan Konseling. Psympathic, Jurnal Ilmiah Psikologi, Vol. III(No.1), 29-36.

Thobroni, M. (2015). Belajar dan Pembelajaran: Teori dan Praktik. Ar-Ruzz Media.

Yanti, S. F. (2017). Pengaruh Pembelajaran Aqidah Akhlak terhadap Perilaku Siswa Di Madrasah Aliyah Negeri Kampar Timur. JOM FISIP, Vol. 4(No. 1), 1-12. 